\title{
Early case of childhood cirrhosis in 1876
}

\author{
Wilson I. B. Onuigbo \\ Department of Pathology, Medical Foundation and Clinic, Nigeria
}

\begin{abstract}
Cirrhosis is a lesion of the liver that was first named in 1847, there being "widespread disruption of normal liver structure by fibrosis." The world-wide nature of it is shown by a Chinese account which mentioned 1934 as the first publication of a type of it. A search of the literature revealed the appreciation of the likelihood of its occurrence being underestimated. The occasional cases have been published. Therefore, this case is promoted as an early one dating to 1876.
\end{abstract}

\section{Introduction}

In Merriam-Webster's Collegiate Dictionary (1), cirrhosis is defined as "widespread disruption of normal liver structure by fibrosis." It was added that the name came into use in 1847.

Of great interest is its epidemiologic manifestations all over the world. For instance, in China (2), as far back as 1961, it was being hoped that postmortem examination will throw light on it. Indeed, 1934 was when it was cited as the first publication of a neonatal form. Others have naturally followed (3-6). Therefore, the case dating back to 1876 is deemed to be worthy of documentation.

\section{Historical case}

Abridgement of the case is in the form as it was delivered for Dr Griffiths of Swansea by Henry Green on December 7, 1875 (7). The specimen of cirrhosis of the liver is from a female child ten years of age, who died on November 17th. It is as follows:

On post-mortem examination the liver was found to be an excellent specimen of a small contracted (cirrhosed) liver [the liver, heart, and kidneys were exhibited at the Pathological Society]. It weighed only 15 ounces; the peritoneal covering was smooth and shiny all over; the whole of the organ was hard, very tough, and irregularly lobulated, and granular on the surface. On section it appeared to the naked eye to consist chiefly of tough fibrous tissue interspersed with irregular lobules (varying in size and colour) of the true liver substance, in different stages of strangulation and degeneration. The portal veins were greatly enlarged. The spleen was as large as the liver, hard and tough.

Remarks. - This is an excellent specimen of a cirrhosed liver from a child aged 10, without any evidence whatever, on the most careful and satisfactory inquiry, of it having been produced by the use of alcoholic drink or irritating food of any kind; neither was there a particle of evidence of hereditary syphilis, of previous history of rickets, diseased bones, or chronic abscess.

Copyright: ( 2017 Onuigbo WIB. This is an open-access article distributed under the terms of the Creative Commons Attribution License, which permits unrestricted use, distribution, and reproduction in any medium, provided the original author and source are credited.

\section{Discussion}

It has been affirmed by Burnet (8) that research deserves to be carried out after looking up historical antecedents. In like manner, Moser (9) was delighted that the "truths" of the day require being traced to yester years! Accordingly, this paper presents the 1876 example of cirrhosis in childhood. I am persuaded that it ranks with others in my vintage historical papers (10-12).

\section{References}

1. Merriam-Webster's Collegiate Dictionary. 11th Edition Merriam-Webster Inc: 419.

2. Chem HC (1961) Hepatitis and cirrhosis in infancy. Acta Pathol Jpn 11:31-35. [Crossref]

3. CRAIG JM, GELLIS SS, HSIA DY (1955) Cirrhosis of the liver in infants and children AMA Am J Dis Child 90: 299-322. [Crossref]

4. Wilkinson EJ, Raab K, Browning CA, Hosty TA (1974) Familial hepatic cirrhosis in infants associated with alphal-antitrypsin SZ phenotype. J Pediatr 85: 159-164. [Crossref]

5. Müller-Höcker J, Meyer U, Wiebecke B, Hübner G, Eife R, et al. (1988) Copper storage disease of the liver and chronic dietary copper intoxication in two further German infants mimicking Indian childhood cirrhosis. Pathol Res Pract 183: 39-45. [Crossref]

6. Burwinkel B, Tanner MS, Kilimann MW (2000) Phosphorylase kinase deficient liver glycogenosis: progression to cirrhosis in infancy associated with PHKG2 mutations (H144Y and L225R). J Med Genet 37:376-377. [Crossref]

7. Griffiths TD (1876) Cirrhosis of the liver in a child aged ten years. Trans Path Soc Lond 27:186-189.

8. Burnet FM (1977) Morphogenesis and cancer. Med J Aust 1: 5-9. [Crossref]

9. Moser KM (1987) Medical truths in historical perspective. Heart Lung 16: 345-346. [Crossref]

10. Onuigbo WI (1971) False firsts in cancer literature. Oncology 25: 163-167. [Crossref]

11. Onuigbo W (2005) An early description of cancer-to-cancer metastasis in 1848. $N Z$ Med J 118: U1315. [Crossref]

12. Onuigbo WIB (2014) An early description of carcinosarcoma in 1883. J Cancer Sci Clin Oncol1: 305.

Correspondence to: Onuigbo WIB, Department of Pathology, Medical Foundation and Clinic, Nigeria, E-mail: wilson.onuigbo@gmail.com

Key words: Liver, cirrhosis, childhood, 1876 case

Received: March 02, 2016; Accepted: March 17, 2017; Published: March 20 2017 